\title{
Current Source Device
}

National Cancer Institute

\section{Source}

National Cancer Institute. Current Source Device. NCI Thesaurus. Code C49903.

An electronic device designed to generate a constant current. 